\title{
Acknowledgments
}

This book has taken many years to complete and bears the sustained labor and support of several communities of scholars, friends, and family. My mentors, Hugh Raffles, Janet Roitman, and Bruce Grant have each spent countless hours of reading and providing critical feedback on the early version of the book. To Hugh I owe many thanks for inspiring a way of thinking ethnographically beyond convention and for reminding me to attend to the pleasures of writing. Janet transformed my way of thinking about money, value, and wealth, in anthropological and philosophical terms. I am thankful for the hard questions and the theoretical challenges that she continues to bring to my attention. In addition to being an encyclopedia of socialist and postsocialist scholarship, Bruce continuously reminded me to question my own common sense and pushed me to provide more thick description of the imponderabilia of everyday life in Albania that I often take for granted. I am thankful to all three of them for the great care that they have continued to provide throughout the past several years. The idea for writing about the pyramid schemes in Albania first emerged in a conversation with Claudio Lomnitz who also provided critical theoretical and methodological insight on the early stages of my research. I am thankful to him for encouraging me to pursue this book. At the New School, my work benefited from the stimulating classes and conversations with Ann Stoler, Gustav Peebles, Ben Lee, Hylton White, and Vyajyanthi Rao.

In Albania, I have benefited from the warm welcome and support by various institutions, old and new friends, and family. I thank in particular Rozeta Koçi who provided research support and friendship and accompanied me during many interviews with former participants in the pyramid firms. I thank Auron Pasha for offering me an internship at the Institute for Development and Research Alternatives (IDRA). I also thank IDRA's staff for the friendship and for helping me identify and contact pyramid schemes' participants. Among others, I thank in particular Florian Babameto, Oni Xhelaj, Emona Ferhati, and Marjeti Dumi.

The Institute of Cultural Anthropology and Study of Art (IAKSA) (then known as the Institute of Ethnology) provided much intellectual support during the time of my research and has continued to be a reference point during subsequent visits to Albania over the years. I thank Gerda Dalipaj, in particular, for the passionate conversations, the walks and runs at liqeni, and for inspiring me with her own research and poetry. During the course of my research and over the past 
several years, Blendi Kajsiu, Armanda Hysa, Eni Papa, Gentiana Kera, Andreas Hemming, Shaban Sinani, and Albert Doja provided feedback and exchanged ideas about my book at various stages. Other friends in Albania, both from the past and made along the way, indulged me on conversations about my research over numerous coffees in the ubiquitous Tirana cafes. Among others, I thank Ada Musaraj, Eldira Gjipali, Alda Skëndaj, Lori Mengri, Jugera Bilali, Mimoza Kaçi, Mirlinda Naçi, and Evis Hoxha for sharing their time and ideas with me.

My time at the Institute for Money, Technology and Financial Inclusion, at the University of California, Irvine in 2012-2014 provided me with yet another community of scholars and friends that pushed me to rethink the scope of this book. I thank Bill Maurer for pushing my thinking about the anthropology of money to the next level and for providing guidance in reframing my arguments in the book to speak to this fascinating literature. I also thank the members of Value and Money writing group, especially Ivan Small, Taylor Nelms, Beth Ready, Stevie Rhea for providing feedback and suggestions on earlier versions of the chapters. In addition, I benefited from conversations with and feedback by the faculty and graduate students of the Department of anthropology at UCI, especially Keith Murphy, Julia Elyachar, Tom Boellstorff, Kristin Peterson, Janny Li, Robbie Kett, Sean Mallin, Nima L. Yolmo, Nathan Dobson, Nathan Coben, and Nick Seaver. I am also thankful to Sean Mallin for a thorough copyediting of the manuscript before production.

Research for this book was funded by the National Science Foundation (DDIG \#0753180), the Social Science Research Council, the Social Sciences and Humanities Research Council, the Council for European Studies and the Society for the Anthropology of Europe, The New School, and the Baker Award. Parts of the interviews and discussion in this book were published in "Tales from Albarado: The Materiality of Pyramid Schemes in Postsocialist Albania," Cultural Anthropology 26, no. 1 (2011). A section of chapter 3 was published in "Pyramid Firms and Value Transformation in Postsocialist Albania," Ethnologie Française 2 (2017). Chapter 1 was published as "The Magic of Pyramid Firms: Cosmologies of Speculation, Repertoires of Credit and Collapsed Finance” in Ethnos (2019). I thank these journals for granting permission to reprint these articles in this book. I have presented drafts of the chapters to various audiences and benefitted from the feedback of faculty and students at the SOYUZ meetings, the UCLA Culture, Power, and Society Colloquium Series, the Cosmoeconomics Workshop at the University of Bergen, the UCSD Socialism in Context Colloquium, and audiences at UCI and Ohio University.

I thank my extended family of fellow scholars, students, and friends with whom I crossed paths and drew much inspiration from during my time living in New York City. Among others, Elga Castro and Miguel Zenon, Hilla Dayan and Peter 
Zuidhof, Carmen Ilizarbe and Juan Pablo Campana, Myrna Alejo, Rose Van Den Breemer and Anstein Gregerson, Sarah (Siddiqui) Wolek, Gabika Boçkaj have all marked the writing of this book through their friendship and intellectual stimulation. I am thankful for the solidarity and emotional support I received from them at the time, especially, Leilah Vanaina, Mateusz Hawala, Randi Irwin, YiYi Hsieh, Monica Fagioli, Ana Maria Ulloa, Zohar Rotem, Karolina Szamagalska (Follis), Charles Townsend, Kadija Ferryman, Gabriel Vignoli, Gregorz Sokol, David Bond, Emily Sogn. I also benefited from conversations with the growing community of Albanian American intellectuals based at the time in New York City; in particular, I enjoyed conversations with Brikena Hoxha, Ajkuna Hope, Elona Pira, Erjola Pira, Blerta Cela, Elidor Mëhilli, and Odeta Xheka. In addition to informing my thinking about Albania in the 1990s, Elidor Mëhilli provided insightful comments and suggestions to the introduction of the book.

During my time of teaching at Ohio University, I benefitted from a number of colleagues who supported me through the revisions of this manuscript. Among others, I benefitted from conversations and friendship of Diane Ciekawy, Haley Duschinski, Nicole Kaufman, Rachel Terman, Elizabeth (Liz) Lee, Stephen (Steve) Scanlan, Christine Mattley, Melissa Figueroa, Ziad Abu-Rish, Alec Holcombe, Assan Sarr, Nukhet Sandal, Myra Waterbury, Marina Peterson, Mariana Dantas, and Victoria Lee. At Cornell University Press, I thank editor Jim Lance for his enthusiasm about this book and I thank Ellen Murphy and Kate Gibson for seeing the book through production.

My family in Tirana, Montreal, and Baltimore is the gift that keeps on giving. I thank first and foremost my parents, Mimoza Musaraj and Vullnet Musaraj, for coping heroically with my and my brother's absence from their everyday life for many years now. I thank them and Penar Musaraj (with Florence Tremblay) for their love and support. In the United States, Susan and Barry Rosen have been a constant source of encouragement. I thank them for their genuine curiosity in my book and for their valuable insights. Last but not least, I thank Matthew Rosen for his inspiration, the intellectual partnership, and for his unfaltering support and confidence in my work. I owe the completion of this long journey to our mutual support, patience, and care as we juggle career, childcare, and life. My daughter, Simone, has grown up around my writing and discussions of this book. I thank her for being able to move seamlessly and enthusiastically across the different worlds of work and life that I have had to bring her along as I complete this long journey. 



\section{TALES FROM ALBARADO}


